\title{
EU RENEWABLE ENERGY POLICY FOR SMART CITIES
}

https://doi.org/10.47743/jopafl-2021-20-02

\author{
Ana-Maria BERCU \\ Alexandru Ioan Cuza University of Iasi \\ Iasi, Romania \\ bercu@uaic.ro \\ Cezar Gabriel BOTEZATU \\ Alexandru Ioan Cuza University of Iasi \\ Iasi, Romania \\ cezargabrielbotezatu@gmail.com
}

\begin{abstract}
The European Union energy policy has been more and more focused on how to become more friendly with the environment and looked for efficient measures to assure the protection of the environment and for sustain the development of the cities through participatory governance: human capital, communication infrastructure (including informational communication systems), economic growth and high quality of life. Because the energy sector has the biggest share of total Greenhouse gas emissions (GHGs), the attention was directed to this sector. Although the EU member states claim that they support the transition from fossil fuels to renewable energy, it is important to see concrete actions into achieving this goal. Our study is structured in two parts: the first one, that includes an analysis of main energy indicators like energy production, energy consumption and share of renewable energy sources (RES) in gross final consumption, based on data available on Eurostat for 2019 and a second part that includes an analysis of the future perspectives and the goals of the EU Member States according to their National Energy and Climate Plans (NECP). The results show that the energy policy is a major factor that has great impact on the development of the smart cities, creating the added value for society.
\end{abstract}

Keywords: smart cities, EU energy policy, innovation, strategy

\section{Introduction}

Smart city is a very dynamic concept that implies the development of the communities using creativity and innovation as a main tool. Using the innovative technologies and artificial intelligence and being oriented for increasing the quality of life of the citizens, the smart city is one of the key concepts for the European policies (European Commission, 2015). The urban development trend is present in European Union and the challenges are to respond to the clean energy policy during the urbanisation process. In this process, the cities are important energy consumers, and the EU energy policy follows to limit the negative effects of the gases emissions through innovative solutions.

Smart city is related to the digital technologies for facilitating the development of the communities and for sustaining the growth of the economies (Bakici et al., 2013). The new energy policies are meant to improve the smart city given the other dimensions of the EU policy and strategies.

Our study is meant to present an analysis of the current situation and future perspectives on the energy sector among the EU member states. The energy policy of the European Union is described by Solorio and Jorgens (Solorio \& Jorgens, 2017:4) as a 'set 
of policy instruments developed at the European level to promote RES between the member states', to achieve the EU's 2030 goals on Greenhouse gas emissions (GHGs). The study is divided into two parts: a first one which includes the analysis of energy production and consumption among the EU member states and the share of renewable energy in gross final consumption in 2019 and their 2030 target and a second part which includes a series of public policy decisions adopted by the EU members to reach the 2030 target.

The subject of decarbonisation was put in the spotlight by the European Union in recent years, as observed by Simionescu, Strielkowski and Tvaronavičienè (Simionescu et al., 2020). One of the main reasons why EU chose to give such attention to the subject of reducing the pollution was exposed by Pablo del Río (Del Río, 2011) and is reperesented by the fact that more than one third of the total GHGs emissions were produced by power generation. Another important fact was illstrated and confirmed by Ranjula Bali Swain and Amin Karimu (Swain and Karimu, 2020) is that there is a link between the renewable energy, especially used when producing electricity, and carbon dioxide emissions reduction.

According to data available on Eurostat (European Commission, 2021), the GHGs emissions generated by the energy sector represented, in 2019, 76.66\% of total GHGs emissions excluding LULUCF. This data represents the motivation for the EU member states to seek for and implement efficient decissions in the energy sector to reduce the air pollution. Thus, the European Union has to find and implement new and less pollutive ways to produce energy and, specially, to generate electricity, but also to reduce the allaraming amounts if GHGs emissions generated in the atmosphere. Furthermore, the EU member states need to strive to assure the succes of these measures, meaning that they must set realistic goals and formulate energy policy decisions in accordance with these goals.

\section{Methodology}

The question that the present research seeks to answer is "are the EU and its member states able to fulfil their energy and climate objectives set for 2030 and 2050?”. The specific objectives of the current study are:

O1: To analyse the data on energy production, energy consumption and share of renewable sources in gross inland consumption registered among the EU member states in 2019.

O2: To analyse the EU member states' National Energy and Climate Plan, the main objectives set for 2030 and the deficiencies of their energy sectors.

O3: To make proposals to improve the energy sectors of member states to ensure that the EU's 2030 and 2050 targets are met.

For the present study there have been used both quantitative information represented by primary energy production, gross inland consumption and share of renewable energy sources in gross inland consumption from Eurostat database, and qualitative information represented by energy policy decisions implemented by the EU member states, to reveal the EU states' perspective on the energy sectors and its future. 


\section{ANALYSIS AND RESULTS}

The main data used to reveal the intensity of the energetic activity of the EU member states were the energy production and the energy consumption. In 2019 the energy production among the EU member states is exposed into table 1, in descending order.

Table 1. Primary energy production on EU member states in 2019

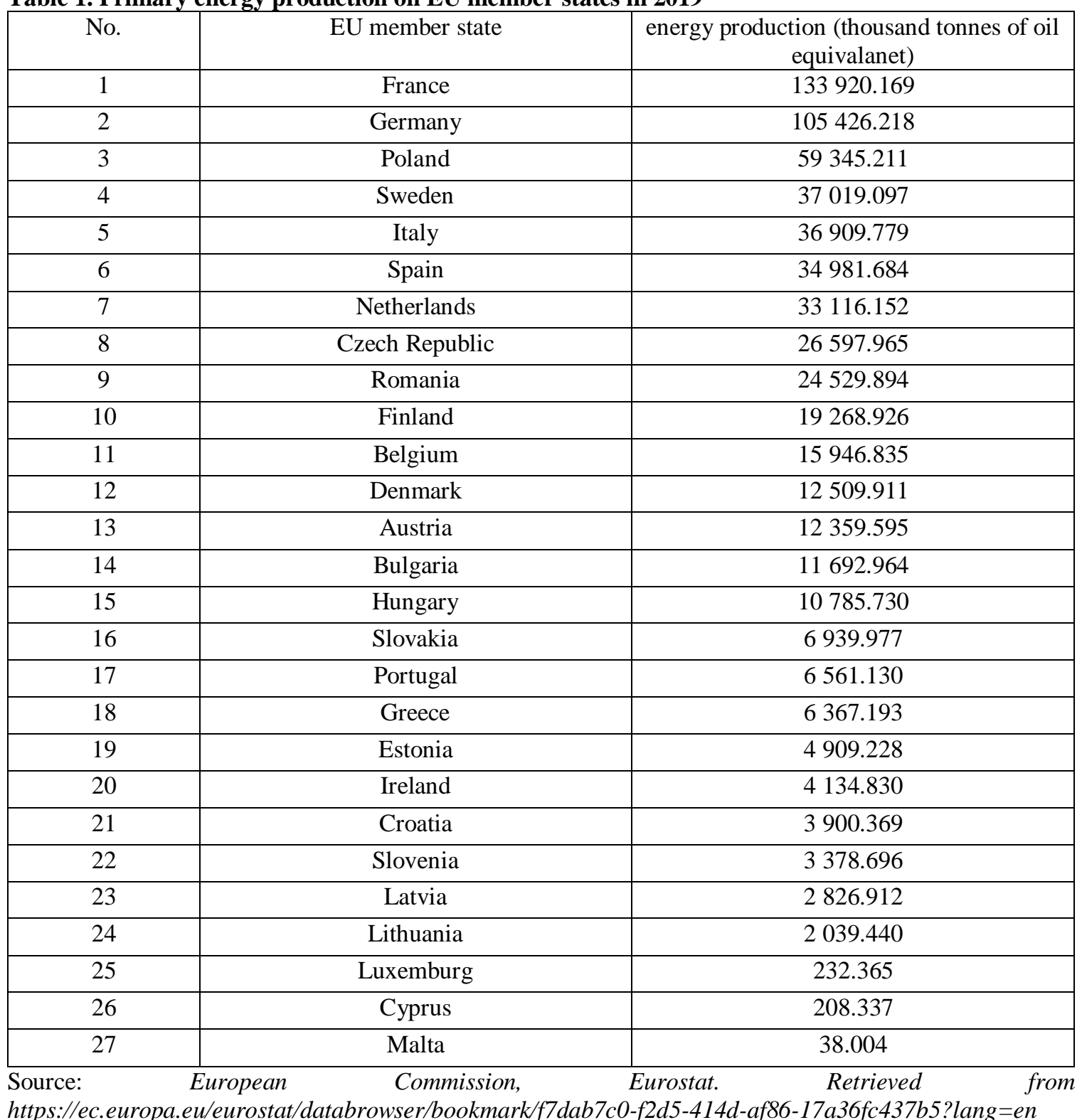

From the data exposed in the table above, it turns out that among the EU member state that has the biggest energy production is France, one of the founding states of the European Union. At the end of the table there are member states with little surface and population, which means the energy requirement is lower than in the other states of the Union. 
On the other side, the energy consumption among the EU states registered in 2019 can be observed in the following table 2.

Table 2. Gross inland energy consumption on EU member states in 2019

\begin{tabular}{|c|c|c|}
\hline No. & EU member state & $\begin{array}{l}\text { Gross inland energy conspumption } \\
\text { (thousand tonnes of oil equivalanet) }\end{array}$ \\
\hline 1 & Germany & 305605.530 \\
\hline 2 & France & 251417.892 \\
\hline 3 & Italy & 155432.667 \\
\hline 4 & Spain & 126969.978 \\
\hline 5 & Poland & 103968.829 \\
\hline 6 & Netherlands & 75932.100 \\
\hline 7 & Belgium & 56777.208 \\
\hline 8 & Sweden & 49703.985 \\
\hline 9 & Czech Republic & 42995.792 \\
\hline 10 & Austria & 34698.218 \\
\hline 11 & Finland & 34234.932 \\
\hline 12 & Romania & 33107.423 \\
\hline 13 & Hungary & 26708.150 \\
\hline 14 & Portugal & 23914.607 \\
\hline 15 & Greece & 23551.592 \\
\hline 16 & Bulgaria & 18847.668 \\
\hline 17 & Denmark & 17313.653 \\
\hline 18 & Slovakia & 17023.933 \\
\hline 19 & Ireland & 14955.497 \\
\hline 20 & Croatia & 8790.716 \\
\hline 21 & Lithuania & 7800.523 \\
\hline 22 & Slovenia & 6721.680 \\
\hline 23 & Estonia & 4824.124 \\
\hline 24 & Latvia & 4649.810 \\
\hline 25 & Luxemburg & 4539.717 \\
\hline 26 & Cyprus & 2630.367 \\
\hline 27 & Malta & 903.139 \\
\hline
\end{tabular}

The biggest energy consumer is Germany, also one of the founding states of the European Union. At the end of the table there can be found the same three states that registered the lowest energy production. Nowadays the analysis of the energy sector of a state only through the production and the consumption of energy can be hallow. The energy sector's impact on the environment has become so big that EU member states started to pay more attention on different indicators, like the share of renewable sources (RES) in gross inland consumption. This indicator reveals the quantity of energy consumed by a state which has been produced with renewable, eco-friendly sources. Among the EU 
member states, the share of RES in gross inland consumption reached values according with data from table 3.

Table 3. Share of renewable energy in gross final energy consumption on EU member states in 2019 and 2020 target

\begin{tabular}{|c|c|c|c|}
\hline No. & Eu member state & $\begin{array}{c}\text { share of renewable energy in } \\
\text { gross final energy } \\
\text { consumption in } 2019(\%)\end{array}$ & 2020 target (\%) \\
\hline 1 & Sweden & 56.931 & 49 \\
\hline 2 & Finland & 43.081 & 38 \\
\hline 3 & Latvia & 40.975 & 40 \\
\hline 4 & Denmark & 37.204 & 30 \\
\hline 5 & Austria & 33.626 & 34 \\
\hline 6 & Estonia & 31.889 & 25 \\
\hline 7 & Portugal & 30.619 & 31 \\
\hline 8 & Croatia & 28.466 & 20 \\
\hline 9 & Lithuania & 25.461 & 23 \\
\hline 10 & Romania & 24.290 & 24 \\
\hline 11 & Slovenia & 21.974 & 25 \\
\hline 12 & Bulgaria & 21.564 & 16 \\
\hline 13 & Greece & 19.667 & 18 \\
\hline 14 & Spain & 18.356 & 20 \\
\hline 15 & Italy & 18.181 & 17 \\
\hline 16 & Germany & 17.354 & 18 \\
\hline 17 & France & 17.216 & 23 \\
\hline 18 & Slovakia & 16.894 & 14 \\
\hline 19 & Czechia & 16.244 & 13 \\
\hline 20 & Cyprus & 13.800 & 13 \\
\hline 21 & Hungary & 12.614 & 13 \\
\hline 22 & Poland & 12.164 & 15 \\
\hline 23 & Ireland & 11.984 & 16 \\
\hline 24 & Belgium & 9.924 & 13 \\
\hline 25 & Netherlands & 8.768 & 14 \\
\hline 26 & Malta & 8.488 & 10 \\
\hline \multirow[t]{2}{*}{27} & Luxembourg & 7.047 & 11 \\
\hline & EU 27 Average & 19.729 & 20 \\
\hline
\end{tabular}

France, the biggest energy producer of EU and Germany, the biggest energy consumer have, according to these two indicators, intense activity in the energy sector, but the problem is the way they produce these big amounts of energy they need. According to the data in Table 3, in 2019 Germany was the 16th member state and France is the 17th EU 
member regarding the share of RES in gross inland consumption and nor France nor Germany managed to achieve the 2020 goal. Even if these two states have similar share of RES, the 2020 goal is different: Germany's goal is to achieve 18\% but France's goal is bigger and reaches $23 \%$ share of RES. As observed above, there are common elements about these two states' energy policy, but there are also differences that make every state's energy policy unique. This situation is encountered into the entire European Union, and this is the reason why it is harder for the EU to achieve its energy and climate objectives.

All the EU member states elaborated in 2019 and 2020 a National Energy and Climate Plan (NECP) which include objectives and targets, but also policies and measures meant to develop a less pollutive and more efficient energy sector. The framework is common for all the member states, meaning that national objectives and targets and also the policies and measures are explained through five dimensions:

- Dimension decarbonization

- Dimension energy efficiency

- Dimension energy security

- Dimension internal energy market

- Dimension research, innovation, and competitiveness.

For this study, there will be used information referring the first two dimensions of the NECPs of the member states.

The first dimension, the one called decarbonization, is the dimension which states that all the EU members must find and implement efficient measures and policies to reduce the greenhouse gases (GHGs) emissions. GHGs emissions is usually measured as part of the level of their gas emissions registered in 1990 and few of the EU states have settled the reduction of the emissions as follows: France (Gouvernment de la Republique francaise, 2020: 6) set a reduction of 40\%, Germany (German Government, 2020: 11) set a reduction of 55\%, Sweden (The Minsitry of Infrastructure, 2020: 5) has set its emission goal for 2045, but it is more ambitious than France's or Germany's goals, because it wants its emissions to represent $15 \%$ of the 1990 level.

States from the middle of the production ranking like Romania, Finland, Belgium, Denmark have also set objectives for the future: Romania (Ministry of Environment, 2020, 11) set a reduction of $40 \%$ by 2030, compared to the level from 1990. Finland (Ministry of Economic Affairs and Employment, 2019: 16) set a reduction of 39\% compared to 2005. Belgium (Federal Government of Belgium, 2019: 13) set a goal to reduce the emission by 35\% by 2030 compared with the 2005 levels of the emissions. Denmark (Danish Ministry of Climate, Energy and Utilities, 2019: 6), the last of the four member states from the middle of the production ranking, wants to reduce its GHGs emissions by $70 \%$ by 2030 , compared to the 1990 level.

At the bottom of the production ranking can be found member states like Luxembourg, Cyprus and Malta. Luxembourg's goal for 2030 (Le Gouvernment de Luxembourg, n.d.: 9) is to reduce its GHGs emissions with 55\% compared to the 2005 level. Cyprus (Ministry of Energy, Commerce, and Industry, 2020: 16) and Malta (The Energy and Water Agency, 2019: 14) don't have a specific goal set for 2030 and they follow the collective EU's target of 40\% GHGs emissions reduction by the year 2030 compared to the levels registered in 1990. The data above reveals the fact that not all the member states have specific objectives to reduce pollution, and they choose to put only enough effort to support the EU’s collective objective for 2030. 
The EU states with more intense activity in the energy sector have set ambitious goals for 2030, meaning that these states assumed that they will radically change the GHGs emissions situation. All the EU member states mentioned above in the NECPs analysis on objectives for pollution reduction, except for Luxembourg, Cyprus, and Malta, have set very ambitious objectives. The biggest goal is Sweden's, which stated that it will reach an 85\% reduction of GHGs emissions compared to 1990. Romania has the lowest percentage of reduction between these seven states, but it is not the same situation as could be observed in Cyprus and Malta. The 40\% reduction is a specific objective mentioned in Romania's NECP and it is not just a statement that claims support for EU's collective target. Even if these percentages seem ambitious and they seem to ease the achievement of the EU's $40 \%$ reduction, it is important to see if these member states' percentages are realistic. For this, it is necessary to correlate the data from the analysis that was made above with the share of RES in gross inland consumption among the EU states.

According to Eurostat (European Commission, 2018), the energy producing industries registered in 2018 the largest share of GHGs emissions, more specifically 28\% of the total GHGs emission came from this sector. The energy producing sector is followed by fuel combustion by users with $25.5 \%$ and the transport sector with $24.6 \%$. The fact that the energy producing sector has a rellevant impact on air pollution has determined the EU member states pay special attention not only to the levels of GHGs emission, but also to the source of these emissions. As it could have been observed above, the EU member states have set goals to reach in 2030, 2045 or even in 2050 regarding the GHGs emissions. These states also set goals for the future regarding the share of RES in consumption. The analysis of the current situation of the share of RES correlated with the future perspectives will support the current study in understanding if the EU states have set realistic goals or those objectives will never be achieved.

Further, the study will continue with the analysis of the same $10 \mathrm{EU}$ member states as above, trying to extract different types of behavior in the energy sector.

The first EU member states mentioned before were France and Germany, the biggest energy producer and the biggest energy consumer respectively. The fact that that they need big energy supplies can be an obstacle on their way to produce cleaner energy, because the transition from fossil fuels to RES involves more effort and financial resources. In France's case, the data from Table 3 shows that France registred a 17.22\% share of RES in 2019 and set a goal to reach 23\% share of RES by 2020. By 2030, France's goal is to reach 33\% share of RES (Gouvernment de la Republique francaise, 2020: 8) in gross final energy consumption. Germany, the second biggest energy producer, had 17.35\% share of RES in 2019 and an 18\% goal for 2020. Its goal for 2030 (German Government, 2020: 11) is to achieve $30 \%$ share of RES in gross final energy consumption. Sweden has a unique situations among the EU member states and can be considered a positive model regarding the transition to renewable sources. With 56.93\% share of RES in gross final energy consumption in 2019, Sweden is the biggest EU renewable energy consumer. Its 2020 target is 49\% share of RES, a goal obviously achieved from 2019. Surprinsingly, in its NECP is mentioned that it "has no national targets for the share of renewable energy in 2030” (The Ministry of Infrastructure, 2020: 19) but according to the same document, The Swedish Energy Agency realised a scenario where the target for 2030 is set to 65\% share of RES in gross energy consumption. Among the EU member states from the middle of the production ranking, the situation is as follows: 
- Romania registered, according to Table 3, 24.3\% share of RES in final consumption, making it the 10th EU state in the ranking of share of RES. It has already overcame its 2020 target of 24\% share. According to Romania's (Ministry of Environment, 2020: 11) the target for 2030 is to reach 32\% renewable energy consumption.

- Finland implementented succesful decisions in the energy sector and it is the second EU member state in the share of RES ranking, with 43.09\%. its 2020 goal to reach $38 \%$ share of RES was obviously overcame in 2019. In its NECP, Finland set its 2030 goal to “at least 51\%” (Ministry of Economic Affairs and Employment, 2019: 17) share of RES in final consumption.

- Belgium registered only 9.92\% share of RES in final consumption, being the 24th EU member state the share of RES ranking. Its 2020 goal is set to $13 \%$, and seems impossible to be accomplished in just one year. According to its NECP, the 2030 goal is to reach 23.5\% share of RES (Federal Government of Belgium, 2019: 57).

- Denmark, the last of the four states in the middle of the production ranking, registred 37.2\% share of RES in 2019, which means that its goal for 2020 is exceeded with more that 7 percents. For 2030, Denmark set a goal to reach 55\% share of RES (Danish Ministry of Climate, Energy and Utilities, 2019: 8).

The EU member states with low energy production have also set goals foar the future regarding the renewable energy sources. Therefore, the current situation of the share of RES and the perspectives for 2030 are these:

- Luxembourg is currently the last EU member state in the share of RES ranking, with 7.04\% share of RES in 2019 and a 2020 target of 11\%. In its NECP (Le Gouvernment de Luxembourg: 9), Luxembourg stated that the 2030 target is to reach $25 \%$ share of RES in gross final energy consumption.

- Cyprus is the 20th member state in the share of RES ranking with $16.2 \%$ share registered in 2019 and it already exceeded its 2020 target, which was set to 13\% share.

- Malta is above Luxembourg in the share of RES ranking with 8,5\% registered in 2019 and 10\% share target for 2020. Its 2030 target is to reach 11.5\% share of RES in gross final energy consumption (The Energy and Water Agency, 2019: 17, a target which is close to the 2020 one.

From the analysis of the share of RES in gross final consumption indicator, there are a few conclusions to be drawn:

- $\quad$ All the EU member states set ambitious targets for 2030, representing an average $10 \%$ growth in share of RES in 10 years. Malta is the EU member state which set the lowest 2030 target, with only 1.5\% higher than the 2020's one. Sweden is the EU's biggest green energy consumer with more than half of its consumption being produced by renewable sources and can represent a role model for the other EU members in implementing the transition from fossil fuels to RES. Even if France and Germany have low shares of RES compared to Sweden, as the biggest green energy consumer or even Romania or Denmark, as smaller energy producers, they predicted big growths of share of RES for 2030.

- $\quad$ It is not enough for the EU member states to set a goal represented by a growth of the share of RES in gross consumption indicator. They need to sustain the achievement of these goals by implementing efficient measures. Some of the most common measures found in the EU states' NECPs are: 
- A carbon dioxide tax whose role is to discourage the companies to produce CO2 emission in states like Germany (German Government, 2019: 62), Sweden (The Minsitry of Infrastructure, 2020: 42) and Finland (Ministry of Economic Affairs and Employment, 2019: 88);

- Measures and schemes to supprot renewable energy consumption, including tax incentives in states lile Sweden (The Minsitry of Infrastructure, 2020: 60), Finland (Ministry of Economic Affairs and Employment, 2019: 95), Romania (Ministry of Environment, 2020: 93) and Luxembourg (Le Gouvernment de Luxembourg: 82)

- Conversion of a coal based electricity production facility to a facility based on natural gas and photovoltaic energy in Romania (Ministry of Environment, 2020: 81);

- Replacing fossil fuels with renewable energy in the transport sector in Finland (Ministry of Economic Affairs and Employment, 2019: 86) and Cyprus (Ministry of Energy, Commerce, and Industry, 2020: 105).

\section{Conclusions}

Our study proposed an analysis of the energy policy of the European Union. More precisely, this study wants to reveal the main EU member states' decisions that sustain the 2030 target achievement regarding the reducing of the carbon dioxide reduction. The main question of the present study is that if the EU member states can completely achieve their 2030 goal regarding the GHGs emissions reduction.

For realizing this study and for giving an appropriate answer to its question, there were set three specific objectives that follows to reveal the current state of the energy policy in the EU Member States and the impact for smart cities development. A first objective which includes the analysis on main energy indicators like production and consumption, and the analysis of the share of RES in gross final energy consumption among the EU member states in 2019. The second objective proposes an analysis of the 2030 EU member states' targets and some of the measures implemented or planned for implementing to support the achievement of these targets. The third specific objective which includes deficiencies and suggestions to fix and improve the EU states' energy policy.

Regarding the first specific objective of the present study, the analysis of the data available on the Eurostat database of the European Commission reveal the current position of the EU Member States in producing energy, consuming, and sharing the RES in final energy consumption. The results show that France is the biggest energy producer and Germany is the biggest energy consumer among the EU states. The data show that the biggest share of RES among the EU member states was registered in Sweden, having a value of over 56 percent. Another fact discovered by analysing the data is that at the end of the production and consumption rankings are the same three EU member states: Luxembourg, Cyprus, and Malta. Malta and Luxembourg are also the member states with the lowest share of RES. The biggest producer and the biggest consumer, France and Germany are below the middle of the share of RES ranking with only $17.35 \%$ share and $17.21 \%$ share, respectively. This ranking will be used further to outline the main measures adopted by the EU member states to reduce the carbon dioxide emissions.

Regarding the second specific objective, there was proposed an analysis of some of the EU member states’ National Energetic and Climate Plans, which include the EU states' 
objectives and targets for 2030 and specific measures to achieve them. One of the measures adopted by the EU member states, an efficient measure according to Swain and Karimu noted (Swain \& Karimu, 2020) was the electrification, because electricity can be produced easier from renewable sources. As observed above, this type of measures were proposed for the transport sector in different countries like Finland and Cyprus and in Romania, as a process of transformation of a coal-based facility to one based on photovoltaic source. Thus, we consider that, from this point of view, the EU member states implement the right decisions to achieve their 2030 goals. Other measures proposed were a carbon taxation based on the 'polluter pays' principle and fiscal incentives for the final consumers who join the transition.

Regarding the third objective of the present study, there are some deficiencies that need to be analysed and revised. The fast development of the electricity production from renewable sources was not harmonized with the development of the grid (Solorio \& Jorgens, 2017: 298), which reduces the posibility of the member states to consume to the fullest that produced energy. An incompatible grid cannot sustain the use of renewable energy, so, even if there are capacities that produce the energy, it would be impossible to contribute to the country's share of RES in final consumption and its growth. Even if some of the EU member states managed to accomplish and even exceed their 2020 target, according to the analysed data, some of them have set high targets for 2020 and were not able to get close to that target in 2019. One good example in this regard is France, which registered 17.2\% share of RES in 2019 and set a target to reach 23\%. The slow process of growing the share of RES in final consumption can lead to a failure in reaching the 2030 not just in the member states, but even at the EU level, as a whole.

Regarding the first deficiency exposed above, we suggest that the EU member states should formulate appropriate strategies after making detailed studies on every aspect of the energy sector. Investments can be partially redirected from building new facilities of production to the development and modernisation of the grid, otherwise the produced energy will never reach the final consumers.

For the second deficiency found in the present study, we consider important that the EU main institutions to get more involved into the states' way on making the transition from fossil fuels to renewable ones. As observed by Solorio and Jorgens, the promotion of using renewable energy has become politicized (Solorio \& Jorgens, 2017: 4) and it would be a mistake by the EU to ignore this aspect. It is very important that the EU drives all its resources, either financial or cognitive, to truly sustain the achievement of these goals for real, not just into political speeches and to respond to a sustainable development of the communities creating smart cities for smart people.

\section{ACKNOWLEDGEMENTS}

This work was supported by Jean Monnet Project „European Smart Cities for Sustainable Development (SmartEU)” no. 620415-EPP-1-2020-1-RO-EPPJMOMODULE. 


\section{References}

1. Bakıc1, T., Almirall, E. \& Wareham, J. A (2013). Smart City Initiative: the Case of Barcelona. $J$ Knowl Econ 4, 135-148. https://doi.org/10.1007/s13132-012-0084-9

2. Danish Ministry of Climate, Energy and Utilities (2019). Denmark's Integrated National Energy and Climate Plan. [Online] Available at: https://ec.europa.eu/energy/sites/ener/files/documents/dk_final_necp_main_en.pdf [Accessed 1707 2021].

3. Del Río, P. (2011). Analysing future trends of renewable electricity in the EU in a low-carbon context. Renewable and Sustainable Energy Reviews, Volume 15, pp. 2520-2533. https://doi.org/10.1016/j.rser.2010.12.013

4. European Commission (2015). Towards an Integrated Strategic Energy Technology (SET) Plan: Accelerating the European Energy System Transformation. In Communication from the Commission C; European Commission: Brussels, Belgium, 6317 final.

5. European Commission (2018). How are emissions of greenhouse gases by the EU evolving?. [Online] Available at: https://ec.europa.eu/eurostat/cache/infographs/energy/bloc-4a.html [Accessed 1707 2021].

6. European Commission, (2021). [Online] Available at: http://appsso.eurostat.ec.europa.eu/nui/submitViewTableAction.do\# [Accessed 2307 2021].

7. Federal Government of Belgium (2019). Belgian Integrated National Energy and Climate Plan 2021-2030. [Online] Available at: https://ec.europa.eu/energy/sites/ener/files/documents/be_final_necp_parta_en.pdf [Accessed 1707 2021].

8. German Government (2019). Integrated National Energy and Climate Plan for Germany. [Online] Available at: https://ec.europa.eu/energy/sites/default/files/documents/de_final_necp_main_en.pdf [Accessed 1707 2021].

9. Gouvernment de la Republique francaise (2020). Integrated National Energy and Climate Plan for France. [Online] Available at: https://ec.europa.eu/energy/sites/ener/files/documents/fr_final_necp_main_en.pdf [Accessed 1607 2021].

10. Le Gouvernment de Luxembourg, n.d. Luxembourg's Integrated National Energy and Climate Plan for 2021-2030. [Online] Available at: http://ec.europa.eu/energy/sites/ener/files/documents/mt_final_necp_main_en.pdf [Accessed 1707 2021].

11. Ministry of Economic Affairs and Employment (2019). Finland's Integrated Energy and Climate Plan. [Online] Available at: https://ec.europa.eu/energy/sites/ener/files/documents/fi_final_necp_main_en.pdf[Accessed 1707 2021].

12. Ministry of Energy, Commerce, and Industry (2020). Cyprus' Integrated National Energy and Climate Plan. [Online] Available at: https://ec.europa.eu/energy/sites/ener/files/documents/cy_final_necp_main_en.pdf[Accessed 1707 2021].

13. Ministry of Environment (2020). The 2021-2030 Integrated National Energy and Climate Plan. [Online] Available at: https://ec.europa.eu/energy/sites/ener/files/documents/ro_final_necp_main_en.pdf [Accessed 1707 2021].

14. Simionescu, M., Strielkowski, W. \& Tvaronavičienè, M., (2020). Renewable Energy in Final Energy Consumption and Income in the EU-28 Countries. Energies 13, Issue 9: 2280. https://doi.org/10.3390/en13092280

15. Solorio, I. \& Jorgens, H., (2017). A Guide to EU Renewable Energy Policy. Cheltenham(Northampton): Edward Elgar Publishing.

16. Swain, R. B. \& Karimu, A., (2020). Renewable electricity and sustainable development goals in the EU. World Development, January, Volume 125. https://doi.org/10.1016/j.worlddev.2019.104693

17. The Energy and Water Agency (2019). Malta's 2030 National Energy and Climate Plan. [Online] Available at: https://ec.europa.eu/energy/sites/ener/files/documents/mt_final_necp_main_en.pdf [Accessed 1707 2021].

18. The Minsitry of Infrastructure (2020). Sweden's Integrated National Energy and Climate Plan. [Online] Available at: https://ec.europa.eu/energy/sites/ener/files/documents/se_final_necp_main_en.pdf [Accessed 1707 2021]. 